\title{
The pastor as model for peaceful existence
}

\begin{tabular}{|c|}
\hline $\begin{array}{l}\text { Author: } \\
\text { Terence Cooke }\end{array}$ \\
\hline $\begin{array}{l}\text { Affiliation: } \\
{ }^{1} \text { Research Associate, } \\
\text { Department of Practical } \\
\text { Theology, University of } \\
\text { Pretoria }\end{array}$ \\
\hline $\begin{array}{l}\text { Correspondence to: } \\
\text { Terence Cooke }\end{array}$ \\
\hline $\begin{array}{l}\text { Email: } \\
\text { terencecooke@telkomsa.r }\end{array}$ \\
\hline $\begin{array}{l}\text { Postal address: } \\
\text { PO Box 5207, Kockspark } \\
\text { 2523, South Africa }\end{array}$ \\
\hline $\begin{array}{l}\text { Dates: } \\
\text { Received: } 25 \text { Jan. } 2011 \\
\text { Accepted: } 27 \text { Sept. } 2011 \\
\text { Published: } 21 \text { Nov. } 2011\end{array}$ \\
\hline $\begin{array}{l}\text { How to cite this article: } \\
\text { Cooke, T., 2011, 'The } \\
\text { pastor as model for } \\
\text { peaceful existence', Verbum } \\
\text { et Ecclesia } 32(2) \text {, Art. \#500, } \\
6 \text { pages. http://dx.doi. } \\
\text { org/10.4102.ve.v32i2.500 }\end{array}$ \\
\hline
\end{tabular}

C 2011. The Authors. Licensee: AOSIS OpenJournals. This work is licensed under the Creative Commons Attribution License.
Many people are disillusioned in the democratic South Africa. That is because they went out from the assumption that with the dawn of democracy, violence would disappear. Unfortunately this did not happen. As with most things in life it is not an either ... or, but a both ... and scenario. In fact, violence is part of the democratic system. Real peace between men and powers can only be the peace of God, the peace which alone heals all disorder. The peace of the world is at best peaceful coexistence, not peace.

In South Africa we have a negotiated agreement to peaceful coexistence, and sometimes, for example, after the miracle of the 1994 election and the euphoria of the World Cups of 1995, 2007 and 2010, we may even think we have achieved real peace. It is indeed in these times of euphoria that the people of South Africa may be tempted to lower our aim and settle for second best thinking that we have arrived.

Model is used not in the sense of the pastor being an example of a peaceful existence to be followed. It is rather used in the sense that a pastor in his or her professional capacity has the knowledge of the meaning of the term 'peaceful existence' and also the hermeneutic competency to apply that knowledge in concrete situations. This opens the exiting possibility that pastors can become travel companions on the road to real peace.

The different aspects of being a pastor, office bearer, professional and person, each contribute to the pastor being a model for peace. It must be emphasised that the different aspects always work together as a unity and the strength of the pastor as a model for a peaceful existence is in the simultaneous application of these aspects in the context in which the pastor lives.

\section{Introduction \\ Violence}

The fact that a conference with this title is held is a testimony that the democratic process in South Africa has at least disappointed some people. Reasons for the disappointment are many and may be or may not be justified. This conference deals with one of the most visible and most devastating reasons for disappointment and that is the continuing occurrence of violence in our society.

We are disappointed because one group of our population lived with a false perception that we were living in a democracy. For them the continuing violence comes as a shock and something new: in the old South Africa we were safe. The other part of our population experienced violence all along the way and they welcomed the democratic process, amongst other reasons, as a way of ending the violence. For many White South Africans this meant the end of 'terrorist' activities, whilst for Black South Africans it meant the end of systemic-judicial and criminal violence.

Both groups were disappointed because we all went out from the assumption that violence and democracy are opposites. That is not true. As with most things in life it is not an either ... or , but a both ... and scenario. In fact, it is part of the democratic system:

It might even be said that a distinctive quality of democratic institutions is their subtle efforts to draw a veil over their own use of violence. There are also plenty of recorded cases where democratic governments hurl violence against some of their own populations. Such violence is called law and order, the protection of the public interest, or the defence of decency against 'thugs' and 'criminals', or 'counter-terrorism'. Within democracies, medical metaphors surface to describe violence as when politicians speak of surgical strikes, sanitary cordons, mopping-up operations and fighting the 'cancer' or 'plague' of terrorism.

(Keane 2004:2)

South Africa became a true democracy at the end of the Cold War and that further strengthened the idea that a nonviolent phase in our history was dawning upon us. Many events since then 
throughout the world proved how naïve that idea was. The first-ever global report on violence (published in 2002) tells something of the bad news: more than 1.6 million people suffer violent deaths every year. Each day, on average, over 1400 people are murdered; roughly 35 people are killed every hour as a result of armed conflict. One quarter of the world's women has suffered sexual violence by an intimate partner (Keane 2004:7).

Is the violence in South Africa then political or criminal violence? The United States Department of State's Bureau of Diplomatic Security (Osac) rates Johannesburg as a 'critical' crime threat (Osac 2011:1). Although the report (Osac 2011:5) rates the threat of political violence as relatively low, it also mentions that South Africa has served as an important transit and facilitation point for global extremists. The report points out the political nature of some forms of violence:

Civil unrest is a concern in Johannesburg, which has been the site for frequent anti-government protests and demonstrations. Gauteng Province (home of Johannesburg) remains the political and economic capital of the country and typically experiences more labour unrest than other provinces (although unrest can, and does, occur in any area). Labour unions in South Africa carry substantial political clout and can quickly mobilize thousands of people to initiate a protest or demonstration.

(Osac 2011:6)

The government in South Africa is not pursuing policies of institutional violence. However, it must be said that the inability of the government to implement sound legal and constitutional principles is one of the major contributors to the continuing state of violence in the country. With regard to the xenophobic attacks in this country the International Organization for Migration (IOM) (2009:16) pointed out three areas of political action that contributed to non-nationals being turned into violable aliens, namely (1) legal status and documentation; (2) related practices associated with arrest, detention, and deportation; and (4) a more general lack of access to constitutional protections through the court and political processes.

The report continues to highlight that many of the attitudes and much of the language used during the May 2008 attacks draw directly from political rhetoric espoused by leaders across the political spectrum (IOM 2009:16). In politics, perception drives action and therefore it must be said that violence in South Africa has a poliical component and the state is at least coresponsible, not only for xenophobic violence, but for violence in general in South Africa.

It is with this world that a pastor is being confronted and to which the pastor needs to turn to and engage with if he or she wishes to fulfil his or her vocation. We now turn our attention to the theme of this article: the pastor as model for peaceful existence and will be treated according to the terms 'peaceful existence' and 'pastor'.

\section{Peaceful existence}

When the term 'peaceful existence' was Googled one of the first hits was 'peaceful coexistence'. That hit resulted in a better understanding of what is happening in our society and also showed the danger if misunderstood:

Peaceful coexistence was a theory developed by the Soviet Union during the Cold War and was adopted by Sovietinfluenced Communist states that they could peacefully coexist with capitalist states. This was in contrast to antagonistic contradiction principle that Communism and capitalism could never coexist in peace.

(Wikipedia 2010)

Rupesinghe (2010) emphasises that to learn to accept difference and to make the world safe for difference will be one of the great challenges for the 21st century. Coexistence is a key phrase in the emergence of a number of great social and political movements. The key characteristic in the definition of the word 'coexistence' is its relation with and acknowledgement that others exist. Peaceful coexistence has indeed become an imperative in the next phase of evolution of civilisation. Furthermore, Rupesinghe (2010:n.p.) states that 'Coexistence between people has become an imperative in the next phase of evolution of civilisation'.

When reading such high praise for this concept it is difficult but necessary to take the sobering thoughts of Thielicke (1969:498) into account. He wrote that real peace between men and powers can only be the peace of God, the peace which alone heals all disorder. The peace of the world is at best coexistence, not peace.

When we read both Rupesinghe and Thielicke, and then attempt to actualise it in the South African context, we must conclude that in South Africa we have peaceful coexistence and not real peace. We have a negotiated agreement to live peacefully together, and sometimes, for example, after the miracle of the 1994 election and the euphoria of the World Cups of 1995, 2007 and 2010, we may even think we have achieved real peace. It is indeed in these times of euphoria that the people in South Africa may be tempted to lower their aim and settle for second best thinking that they have arrived.

\section{Peace}

We now turn our attention to this higher goal, namely peace. Peace has been defined by many authors, but no single definition has been able to put the full meaning into a sentence or short paragraph and it will not be attempted again. The following remarks on peace will be sufficient.

\section{Peace is a central theme in Scripture}

Peace and the threat to peace are present from the very first pages of Scripture. Genesis tells us about the complete peace and harmony in the beginning as well as the disturbing of that peace. Revelation ends with that complete peace and harmony restored. Likewise human history is one of the human race's involvements in war and its never-ending endeavour for peace (De Villiers 1990:11). 


\section{Peace is an all embracing concept}

For many people peace is the period of calm between wars. It is more than that. For others it is harmony and balance (Nouwen 1997:30). Again it is all that plus much more.

To move beyond peaceful coexistence to real peaceful existence we need to go back to and depart from the Old Testament concept of 'Sjalom' (De Villiers 1990:12). Koehler and Baumgartner (1985:1131) give the meaning as complete, intact and peaceful.

The author understands peace as an all inclusive concept, including all people and all aspects of life. For pastors to be a model of a peaceful existence, they need to understand this all inclusiveness. This understanding must lead to a turnaround of the natural human inclination to narrow borders and rather seek to expand it (Nicol 1990:99). Pastors need to broaden their vision and realise that they need to cross borders all the time to fight against and eradicate all forms of alienation, poverty and oppression. At the same time they need to promote social harmony and wholeness in the community. This need to expand the vision for peace should include all relationships in which a human being exists. Here a word of caution is needed. Humans have a special talent to disassemble things and in our relationships we have disassembled to the point that we think it possible to be busy with one of our many relationships without it having any effect on the other. Nothing can be further from the truth. It is maintained that the relationship to God will always be of primary importance and is the foundation of all other relations and that peace is only possible when people live in the right relationship with God and obey him. It is not possible, however, to be in a relationship with God without it having an effect on all our other relationships, and vice versa.

At this particular point in human history our relationship with Creation is of particular importance in our quest for peace. It is important to realise that the current ecological debate and social issues like poverty and Aids mutually affect one another. Poverty and economic injustice can lead to ecological problems like overpopulation and deforestation. Likewise are ecological problems the cause of poverty and human suffering (Conradie 1996:116). It has often been said that World War III will be fought over water. It will do mankind no good if we are at peace with one another, without a space to live that peace in.

\section{No peace without justice}

Scripture is clear that no real or lasting peace is possible without justice (De Villiers 1990:14). It is imperative, not only to end hostilities but also to remove the causes of hostilities and injustice. If anybody makes peace without removing the cause, it only serves to deepen the alienation between people and groups of people (Nicol 1990:99).

It is at the junction between peace and justice that many pastors fail to engage. If asked why, they often reply that is for the sake of peace. In reality they then become stumbling blocks in the way of peace. It must be clear that a pastor cannot fail to engage, but there is more than one way to engage. Deist (1982:58-65) described the different ways in which people in Germany reacted to the Nazi regime. It ranges from Colonel Stauffenberg who placed the bomb at Hitler's feet, through pastor Bonhoeffer who became an activist against Hitler to the commander of a concentration camp who risked his life to obtain medicine from inmates from military supplies. When the camp was freed, the inmates grabbed the commander and would not release him before an American officer guaranteed that he would not be persecuted. But there were also Christians who worked as prison guards and treated Bonhoeffer humanely and smuggled his letters from prison. Deist comes to the conclusion that each one acted in accordance with his or her conscience and understanding of the situation. Therefore it is impossible, even with the wisdom of hindsight to judge on who was right or wrong. Likewise pastors in the 21st century have no excuse not to engage, because of the various possibilities of engagement. Our lack of engagement still needs to be confronted with Bonhoeffer's question: 'Must the church always be late?' (Bonhoeffer 1971:12).

\section{In promoting peace both the context of Scripture and the situation must be considered}

It is of utmost importance for any theologian to take into account the context of both Scripture and the situation in which it must be proclaimed. It has always been one of a pastor's biggest temptations to draw direct lines between Scripture and the contemporary situations in which it must be applied. In the case of peace it has more often than not led to ideological preaching and a justification of the preacher's view on the causes of conflict and the way to peace. The problem with this usage of Scripture is that the pastor tries to bridge the distance between the text and today by himself herself. That is something that only God can do (Cilliers 1996:48). The dangers of such usage of Scripture need not be argued here.

Why this is happening remains a riddle, because pastors are trained to read and interpret religious texts in a responsible way (Jeroense 2000). In addition to that pastors are supposed to be able to analyse people and their situations in the framework of the gospel. Van Dam (2004:22) describes this as the capability of the pastor to work independently with Scripture, to have insight in theological tradition and to be able to make an independent a responsible theological analysis.

Pastors should bear in mind the rich results if they can be faithful and successful in the quest for peace. It is nothing less than the opening up of new possibilities for all of humankind indeed for the earth itself. It is the creation of a new way of being human; it gives the earth a breathing space (Nicol 1990:98). With these remarks on peace the direction for the pastor has been outlined; settle for an all embracing best and not second best. 


\section{The pastor as model for peaceful existence}

Now the focus shifts to the pastor as the person that has a very specific role in the realisation of this peace. Model is used in this article not in the sense of the pastor being an example of a peaceful existence to be followed, but it is rather used in the sense that a pastor in his or her professional capacity has the knowledge of the meaning of the term 'peaceful existence' and also the hermeneutic competency to apply that knowledge in concrete situations. This opens the exiting possibility that pastors can become travel companions; companions of one another. Companions of members of their congregation and denomination, and indeed, companions of the whole of humankind. When the pastor becomes a travel companion, he or she departs on a journey with people for shorter or longer time. He or she interacts with those people, talking to them about what happened and is happening. In this interaction both experience their marvel of the great God we serve (Van der Meulen 2004:50). The real marvel, however, becomes clear when both realise that a Third has joined the journey, the Lord himself (Van der Meulen 2004:79).

\section{The pastor}

As in the case of peace, there are definitions in abundance for the pastor, but none sufficient. Therefore Heitink's model (Heitink 2001:181) as adapted by Cooke (2008:26) will be used to describe the pastor and his or her role in promoting peace.

When different aspects of being a pastor are distinguished, it must be remembered that they form a unity and that the different aspects can never be totally separated from one another. They work in on one another to keep the balance between them. When the person of the pastor is emphasised it serves as a correction against an overvaluation of the office of the pastor in which het tegenover van het ambt is emphasised (Heitink 2002:212). When at other stages the office is emphasised it is a caution against overspecialisation in the careers of pastors. When the focus is on the career of the pastor it creates space for the person and office of the pastor to develop.

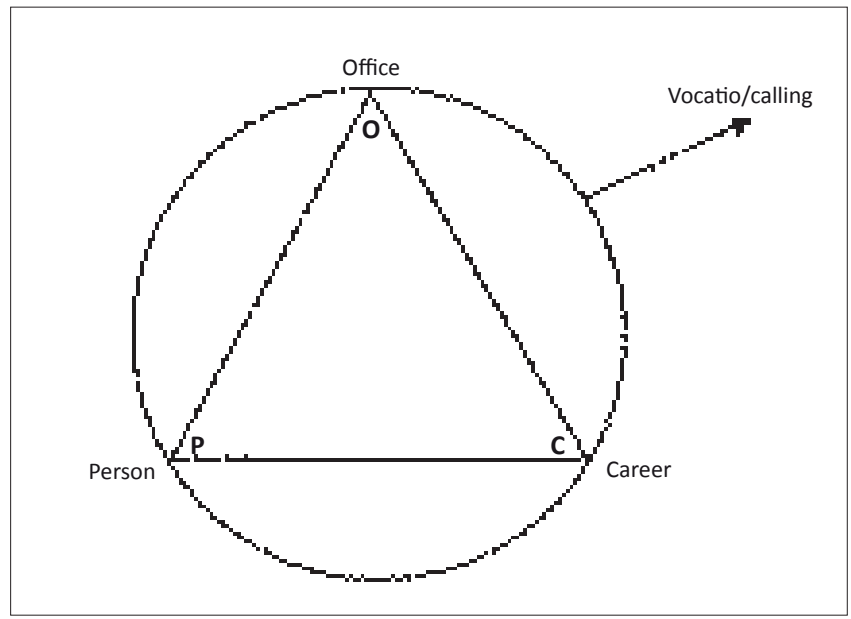

FIGURE 1: The pastor.

\section{Calling}

The calling of the pastor is not something unique to the pastor or of a higher degree as the calling of other believers; the vocation particularis (Bavinck 1967:iv) is the faith community (Cooke 2008:44). Rulla (1988:4) described this calling as an invitation from and a gift through which God invites a pastor to devote himself or herself to this ministry. Promoting peace in the world, as shown earlier, forms an integral part of this ministry.

\section{The pastor as office bearer}

Contemporary pastors are not always comfortable with being office bearers because it implies a position of authority and in our times there is distrust in any authoritarian position. The Lord is my Shepherd, but the shepherd does not want to be lord. As pastors we cannot escape the fact that authority is part of the calling ( $\mathrm{Nel}$ 2002:56). However, the plea is not for authority to control people but for intelligent authority (Hiltner1958:67). Van Niekerk (2006) describes it as follows:

Christene se voorbeeld is Christus. Vroeg in sy openbare optrede, pak Jesus die godsdienstige gesagdraers se interpretasie van die gebooie met mening. Aan die einde van die Bergrede is die skare verbaas omdat Jesus met gesag geleer het en nie soos die Skrifgeleerdes nie (Mat 7: 28-29).

Hoekom straal Jesus gesag uit, maar die tradisionele gesagdraers nie? Vir Ferdinand Deist is die enigste oplossing dat daar verskillende soorte gesag is. Ook woordeboeke lys dat 'gesag' op 'mag' sowel as op 'invloed' kan dui.

Die Skrifgeleerdes en talle godsdienstiges vandag-meen gesag is mag wat mens van bo af op ander uitoefen. Daar is situasies waar die soort gesag nodig bly. Die staat moet sy mag gebruik om misdadigers af te skrik. Maar wanneer Christene deur die mag van boikotte sangers wil keer, gaan hulle dié ouens se saak net adverteer. Jesus se gesag werk anders. Dit wil mense se harte beïnvloed. Dis 'n gesag wat dring maar nie dwing nie. Daarom oorreed Jesus mense deur gelykenisse en dreig Hy nie. Hy spel die een lewenstyl se voordele uit teenoor 'n ander. Boonop vergewe Hy. Diegene wat Hy waarsku en berispe, is 'gelowiges' wat God se genade onnodig vind.

Ons word gevra om Christus se liefde, vergifnis en selfs lyde te volg. Al wat ons nie moet volg nie is God se toorn. Aan Hom alleen kom die mag van wraak toe. Net Hy kan vergeld.

(Van Niekerk 2006:10)

The importance of pastors as officials of the church of Jesus in Christ in promoting real peace cannot be under-estimated.

\section{The pastor as professional}

The competencies that are required of a pastor are many and here only a few are mentioned that have direct implications for the promoting of peace.

\section{Hermeneutical competency}

This is the ability to interpret the stories of people and of God and even more to connect them. The pastor must be able to commute between man and God and know when and for how long to stay with each. 


\section{Communicative competency}

This includes the pastor's communication with God and with other people. It also includes the ability to listen with empathy.

\section{Integrity}

Integrity is a high standard of living based on a personal code of morality that does not succumb to the whim of the moment or the dictates of the majority (Ezell 1995:83).

\section{Creativity}

The more technology develops and becomes available for the broader population, the more the pastor will have to compete with other sources for the attention of believers. This means finding new vehicles to convey the message of peace without changing it (Cooke 2008:67). Specialising is very popular amongst pastors and to a certain extent is a very good development. There are dangers though, specifically for the promotion of peace. The pastor is about the only general practitioner left in the field. That means that the pastor has a certain versatility that only he or she can bring to the process and that makes the pastor indispensable in the quest for real peace. The church must protect and strengthen this quality of its pastors.

\section{The pastor as person}

In the field of professionals the pastor is the one person where who he or she is cannot be separated from what he or she is doing. We also live in era where the person of the pastor is becoming more and more important (Heitink 2002:205). It is also true that when a church or congregation wants change there are three popular quick fixes: people, programmes and policy. The most popular fix is to change the pastor (Rendle 1998:35).

When speaking about pastors, it can be said that we are all equally qualified for the ministry, but that we are not all equally fit for it. In the triangle of office, career and person, the person is the big variable. It is this variable that is of cardinal importance in the ministry and especially for the peace mission of the church. Much can be said about the person of the pastor, but in regard to the peace he or she is to model only the following is emphasised.

\section{Self-acceptance}

All people, pastors included, suffer from the discrepancy between what we want to be and what we really are. In the case of pastors that discrepancy is aggravated by another discrepancy, that between our perceptions of what the church should be and what it really is. Rulla (1988:74) pointed out that many people make a decision on entering the ministry based on idealistic perceptions. Many pastors do not know how to manage these discrepancies in their own life as well as in the church. In the ensuing struggle to cope with it, many pastors have unfortunately ceased to be instruments of peace and instead become instruments of strife.
To become instruments of peace, pastors will have to accept their strengths as gifts from God and their weaknesses as his charge. If a pastor can learn to take care of himself as for a neighbour he will be able to bring real peace to the neighbour as well (Wijngaarden 1969:66).

\section{Introspection}

Introspection is the possibility to view and examine oneself. The danger is of course that a person can be so busy with the self that there is little productivity (Heitink 1997:325). It is important to note that even this introspection does not take place in isolation. Bosman (2001:430) pointed out that it always takes place in a relationship. Pastors must realise that if they find peace with God it immediately opens possibilities for peace with the other people of God.

\section{An experience-based spirituality}

Since the latter part of the 20th century spirituality has become a blanket and open-ended term for anything that concerns the spiritual life of a human being (Waaiman 2003:362). If the pastor wants to be a model for a peaceful existence they need to follow the direction indicated by Van der Meulen (2004:21). That is to seek out places where the loving presence of God, which is far more wonderful than the human mind can understand, can be found. Spirituality suggests the relationship between the Spirit of God [Spiritus Sanctus] and the spirit of man [Spiritus Hominis]. In this relationship man stands open and naked before the Holy One.

This relationship is of ultimate importance in modelling peace. The gap between people and the church is widening, but the same people that are moving away from the church are still seeking for a form of spirituality (Heitink 1996:23). A pastor that is a well experienced traveller with God can bridge that gap.

With these remarks on the person of the pastor it is suggested that in his person the pastor must not only be a person who does peace or proclaim peace, but one who is peace. The different aspects of being a pastor and its contribution to being a model for peace has been highlighted but it must be emphasised that these different aspects always work together as a unity and the strength of the pastor as a model for a peaceful existence is in the simultaneous application of these aspects in the context in which the pastor lives.

The danger for peace is that pastors might choose not to engage but to disengage. They choose not to engage because the challenge is too daunting. Reading books like The unnecessary pastor (Dawn \& Peterson 2000) and chapters like "Om de toekomst van een overbodig beroep" (Heitink 2002:255-294) does not help either.

Pastors must remember that their work is achieved by trusting on the promise of the Lord and that we will never be alone. Pastors that want to disengage from this process can continue to engage because God keeps his word as Father, Son and Holy Spirit (Jentsch 1982:318-32). 
Uncertain pastors can continue because the Father pays attention to them. Failed pastors can continue, because Jesus did not give up on them, as with Peter the night before the crucifixion. Overextended pastors can continue because the Holy Spirit gives them power of attorney.

\section{Acknowledgements \\ Competing interests}

The author declares that he has no financial or personal relationship(s) which may have inappropriately influenced him in writing this article.

\section{References}

Bavinck, H., 1967, Gereformeerde dogmatiek IV, Kok, Kampen.

Bonhoeffer, D., 1971, Treue zur welt - Meditationen, Kaiser Verlag, München.

Bosman, L.L., 2001, ' $n$ Narratiewe Beskouing van die pastoraal terapeutiese self in ' $n$ postmoderne samelewing, DD proefskrif, Departement Praktiese Teologie, Universiteit van Pretoria, Suid-Afrika.

Cilliers, J., 1996, Die uitwissing van God op die kansel, Lux Verbi, Kaapstad, Suid-Afrika. Conradie, E., 1996, Rus vir die hele aarde, Lux Verbi, Kaapstad, Suid-Afrika.

Cooke, F.T., 2008, Die gebruik van die pastor pastorum in die pastorale versorging van predikante van die NG Kerk, DD proefskrif, Departement Praktiese Teologie, Universiteit van Pretoria, Suid-Afrika.

Dawn, M.J. \& Peterson, E.H., 2000, The unnecessary pastor, Regent College Publishing, Vancouver.

De Villiers, D.E., 1990, 'Die prediking oor vrede', in C.W. Burger, B.A. Muller \& D.J. Smit (eds.), Riglyne vir die prediking oor vrede, pp. 1-15, Lux Verbi, Wellington.

Deist, F.E., 1982, Sê God so, Tafelberg, Kaapstad.

Ezell, R., 1995, Ministry on the cutting edge, Alban Insitute, Washington.

Heitink, G., 1984, Pastoraat als hulpverlening, Kok, Kampen.

Heitink, G., Körver, J., Van den Berg, M. \& Dullaert, R., 1996, Pastoraat en geestelike gesondheidsorg, Ambo, Baarn.

Heitink, G., 2002, Biografie van de dominee, Ten Have, Kampen.
Hiltner, S., 1958, Preface to pastoral theology, Abingdon, Nashville.

International Organization for Migration, 2009, 'Towards Tolerance, Law, and Dignity: Addressing Violence against Foreign Nationals in South Africa', viewed 29 July 2011, from http://www.observatori.org/paises/pais_77/documentos/violence against foreign nationals.pdf

Jentsch, W., 1989, Der seelsorger, Brendow Verlag, Moers.

Jeroense, J., 2000, 'De Predikant is theoloog!', Woord en Dienst 49, 24.

Kaptein, R., 1966, De Predikant, zijn plaats en zijn taak in een nieuwe wêreld, Poal en van Gennep, Amsterdam.

Keane, J., 2004, 'Violence and Democracy', viewed 30 June 2010, from www. johnkeane.net/pdf_docs/violence introduction.pdf

Koehler, L. \& Baumgartner, W., 1985, Lexicon in veteris testamenti libros, E.J. Brill, Leiden.

Louw, J. \& Nida, E. (eds.), 1988, Greek-English Lexicon, UBS, New York.

Merriam-Webster Dictionary n.d., www.merriam-webster.com/dictionary/ coexistence, viewed 03 July 2010.

Nel, M., 2001, Ek is die verskil, CLF, Bloemfontein, Suid-Afrika.

Nicol, W., 1990, 'Matteus 5:9', in C.W. Burger, B.A. Muller \& D.J. Smit (eds.), Riglyne vir die prediking oor die Bergrede, pp. 94-103, NG Kerk Uitgewers, Kaapstad, Suid-Afrika.

Nouwen, H., 1997, Bread for the journey, Harper, San Francisco.

United States Department of State Bureau of Diplomatic Security, 2011, 'South Africa 2011 OSAC Crime and Safety Report: Johannesburg', viewed 29 June 2011, from www.osac.gov/Pages/ContentReportPDF.aspx?cid=10935

Rendle, G.R., 1998, Leading change in the congregation, Alban Institute, Washington.

Rulla, L.M., Imoda, F. \& Ridick, J., 1988, Psychological structure and vocation, Gregorian University Press, Rome.

Rupesinghe, K., 2010, 'What is coexistence', viewed 29 May 2011, from http://www. gppac.net/documents/pbp_f/part1/5_coexis.htm

Thielicke, H., 1969, Theological ethics, Vol II Politics, Fortress Press, Philadelphia.

Van Dam, G., 2004, Dichter bij het onuitspreeklijke over geestelijke begeleiding voor en door pastores, Ten Have, Baarn.

Van der Meulen, H.C., 2004, De pastor als reisgenoot: Pastoraal-theologische gedachten over geestelijke begeleiding, Uitgeverij Boekencentrum, Zoetemeer.

Waaijman, K., 2003, Spiritualiteit, vormen, grondslagen, methoden, Kok, Kampen.

Wijngaarden, H.R., 1969, Hoofdproblemen der volwassenheid, Bijleveld, Utrecht.

Wikipedia, 2010, 'Peaceful coexistence', viewed 13 October 2010, from http:// en.wikipedia.org/wiki/Peaceful_coexistence

Wikipedia, 2007, 'Peace', viewed 13 July 2010, from http://en.wikipedia.org/wiki/ Peace 